\title{
Effects of Flooding and Anoxia on Activities of Alcohol Dehydrogenase and Lactate Dehydrogenase in Maize Seedlings
}

\author{
Hisashi Kato-Noguchi, Takuya KoRI and Hideo SaIto \\ Department of Biochemistry and Food Science, Faculty of Agriculture, Kagawa University, \\ Miki-cho, Kagawa 761-0795, Japan
}

(Received May 14, 1999)

\begin{abstract}
To investigate the effects of flooding and anoxic stresses on respiratory metabolism in maize (Zea mays L.), the seedlings of two cultivars (cv. Jelly Bantam and Popcorn) were subjected to the stresses, and the activities of alcohol dehydrogenase (ADH) and lactate dehydrogenase $(\mathrm{LDH})$ were determined. The relative importance of lactic and ethanolic fermentation was also characterized under such conditions. Flooding and anoxic stresses increased ADH activity in shoots and roots of two cultivars but the stresses did not increase LDH activity. The increases were greater in the roots than in the shoots of both cultivars under the flooding and the anoxic stresses, and greater in cv. Jelly Bantam than in cv. Popcorn under the flooding stress. Using polyacrylamide gel electrophoresis, only one ADH band was identified in extracts of the shoots and the roots of both cultivars under non-stress and three ADH isozemes were identified in the extracts under the stresses, which indicates that ADH subunit translation is increased by the stresses. These results suggest that the flooding and the anoxic stresses increase ADH activitiy in shoots and roots of two cultivars of maize but stresses do not increase LDH activitiy, and increased ADH activity may be due to increased synthesis of the enzyme.
\end{abstract}

\section{INTRODUCTION}

During the growing season, anoxia often occurs in field crop plants when they are exposed to flooded or waterlogged soil (Lin and Lin, 1992; Voesenek et al., 1997). Anaerobic conditions in plants result in rapid changes in respiratory metabolism and in the pattern of related gene expression (Sachs and Ho, 1986; Millar et al., 1994; Ricard et al., 1994). Glycolytic metabolism in many plants is accelerated in such a condition and the increase in glycolytic flux is accompanied by the accumulation of glycolytic end products including ethanol and lactate (Roberts et al., 1984 ; Kennedy et al., 1992; Good and Muench, 1993). Ethanol is formed by reduction of acetaldehyde by alcohol dehydrogenase (ADH) and $\mathrm{NADH}$, which is preceded by decarboxylation of pyruvate to acetaldehyde by pyruvate decarboxylase (PDC) in the ethanolic fermentation pathway. Lactate is formed by the reduction of pyruvate by lactate dehydrogenase (LDH) and NADH in the lactic fermentation pathway. Therefore, many plants have two simultaneous pathways competing for pyruvate and NADH under anaerobic condition (Davies, 1980; Kennedy et al., 1992) and these alternative fermentation pathways allow glycolysis to continue owing to consumption of pyruvate and regeneration of NAD (Kennedy et al., 1992 ; Ke et al., 1994).

Different plant species show wide differences in their flooding tolerance and ADH is considered essential for anoxia survival since the ADH null mutants of plants are more 
sensitive to flooding and concomitant anoxia (Davies, 1980 ; Ricard et al., 1994 ; Zhang and Greenway, 1994). In addition, ADH was necessary for removal of acetaldehyde because of its phytotoxic effect (Perata and Alpi, 1991) and for cytoplasmic pH regulation (Roberts et al., 1984). The objective of this study was to investigate the effects of flooding and anoxic stresses on two cultivars of maize seedlings and to characterize the relative importance of lactic and ethanolic fermentation under such conditions. Thus, the activities of LDH and ADH were determined in shoots and roots of the seedlings and $\mathrm{ADH}$ isozymes were characterized.

\section{MATERIALS AND METHODS}

Plant materials. Two cultivars of maize (Zea mays L.) were used : cv. Jelly Bantam and Popcorn. Maize seeds were sterilized in a $2 \%(\mathrm{w} / \mathrm{v})$ solution of sodium hypochrorite for 15 min, rinsed in tap water for $2 \mathrm{~h}$ and germinated on two sheets of moist filter paper (No. 1 ; Toyo Ltd., Tokyo) at $25^{\circ} \mathrm{C}$ in daily cycles of 12-h-light and 12-h-dark in a growth chamber. Light was provided from above with a white fluorescent lamp $\left(3.2 \mathrm{~W} \mathrm{~m}^{-2}\right.$ at plant level ; FL40SSW, National, Tokyo). After $2 \mathrm{~d}$, uniform seedlings were selected and transferred to 9-cm Petri dishes each containing two sheets of filter paper moistened with $10 \mathrm{~mL}$ distilled water. After being kept in the same daily cycle for one further day, the seedlings were used for flooding and anoxic treatments.

Flooding treatments. The Petri dishes were placed in plastic containers and the containers $(30 \times 60 \times 45$ (height) $\mathrm{cm})$ were filled with $25^{\circ} \mathrm{C}$-distilled water. The seedlings were completely submerged in the distilled water (about $3 \mathrm{~cm}$ below the water surface) and the containers were kept at $25^{\circ} \mathrm{C}$ in a growth chamber. For determination of enzyme activity, two-four Petri dishes were removed daily from the plastic containers and the seedlings were divided into shoots and roots using a razor blade and stored immediately at $-80^{\circ} \mathrm{C}$ until extraction. Control seedlings were kept in air in the plastic containers at $25^{\circ} \mathrm{C}$ in the growth chamber and harvested as described above.

Anoxic treatments. The Petri dishes with the 3-d-old seedlings were placed into a 5-L gas changing desiccator at $25^{\circ} \mathrm{C}$ in a growth chamber. Distilled water $(200 \mathrm{~mL})$ was placed at the bottom of the desiccator to maintain a relative humidity and the Petri dishes were set above the water. Then, the desiccator was purged with nitrogen gas at a rate of $1000 \mathrm{~mL}$ $\min ^{-1}$ for $20 \mathrm{~min}$ and the gas purge was performed every $12 \mathrm{~h}$ to maintain the anoxic condition. Control seedlings were purged with air at a rate of $1000 \mathrm{~mL} \mathrm{~min}^{-1}$ for $20 \mathrm{~min}$ at 12 -h intervals. For determination of enzyme activity, the seedlings were harvested and stored as described above.

Extraction and assay of enzymes. Frozen shoots and roots of maize seedlings were homogenized in four volumes of ice-cold solution containing $100 \mathrm{mM}$ Tris- $\mathrm{HCl}(\mathrm{pH} \mathrm{8.0)}, 2$ $\mathrm{mm}$ EDTA, $1 \mathrm{~mm} \mathrm{MgCl} 2$ and 5\% (v/v) glycerol. The homogenate was centrifuged at $25000 \times$ $g$ for 30 min and the supernatant was used immediately for the measurements of ADH and LDH activities.

ADH and LDH activities were determined spectrophotometrically by monitoring the oxidation of $\mathrm{NADH}$ at $340 \mathrm{~nm}$ for $15 \mathrm{~min}$ at $30^{\circ} \mathrm{C}$ in the following $1-\mathrm{mL}$ reaction mixture. The assay mixture for ADH contained $85 \mathrm{~mm}$ MES (pH 6.5), $0.15 \mathrm{~mm}$ NADH and $0.02 \mathrm{~mL}$ sample, and $5 \mathrm{mM}$ acetaldehyde to initiate the reaction as described by Kato-Noguchi and Watada (1997). The assay mixture for $\mathrm{LDH}$ contained $100 \mathrm{~mm}$ Tris- $\mathrm{HCl}$ (pH 8.0), $0.24 \mathrm{~mm}$ NADH, $5 \mathrm{~mm}$ 4-methylpyrazole, $1.5 \mathrm{~mm} \mathrm{Na}$-pyruvate, and $0.2 \mathrm{~mL}$ of sample. 4-Methylpyrazole was used to inhibit interference from the coupled action of PDC and ADH (Hoffman et al., 1986). The overall recovery of the enzyme activity through the quantification process was $87 \pm 5$ and 
$84 \pm 7 \%$ for $\mathrm{ADH}$ and $\mathrm{LDH}$, respectively, according to 5 repeated assays with pure enzyme in the extract.

Protein was determined by the method of Bradford (1976) using bovine gamma-globulin as a standard.

Polyacrylamide gel electrophoresis. Frozen shoots and roots of maize seedlings were homogenized and extracted as described in the above and applied to native slab polyacrylamide gel electrophoresis. Each gel track contained $10 \mu \mathrm{L}$ of sample plus $10 \mu \mathrm{L}$ of $90 \%$ glycerol containing $0.01 \%$ bromophenol blue. The running gel containing $14 \%(\mathrm{w} / \mathrm{v})$ acrylamide, $0.42 \%$ bisacrylamide, $0.37 \mathrm{M}$ Tris- $\mathrm{HCl}(\mathrm{pH} 8.5)$ and $12 \%(\mathrm{w} / \mathrm{v})$ glycerol, was polymerized with $0.9 \mu \mathrm{L} \mathrm{mL}^{-1}$ TEMED and $0.4 \mathrm{mg} \mathrm{mL}^{-1}$ ammonium persulfate. The stacking gel containing $5 \%$ acrylamide, $0.2 \%$ bisacrylamide, $0.12 \mathrm{M}$ Tris- $\mathrm{HCl}(\mathrm{pH} 6.7)$ and $12 \%$ glycerol was polymerized with $0.6 \mu \mathrm{L} \mathrm{mL}^{-1}$ TEMED and $0.3 \mathrm{mg} \mathrm{mL}^{-1}$ ammonium persulfate for $2 \mathrm{~h}$. Gels were run with Tris-glycine buffer ( $\mathrm{pH} \mathrm{8.8,10} \mathrm{mM} \mathrm{Tris,} 77 \mathrm{~mm}$ glycine) in both electrode tanks at $15 \mathrm{~mA}$ at $4^{\circ} \mathrm{C}$. When the dye front migrated to the bottom of the running gel, the gel was stained in a $50 \mathrm{~mL}$ solution containing $0.1 \mathrm{M}$ Tris- $\mathrm{HCl}(\mathrm{pH} 8.0), 0.7 \mathrm{mM} \mathrm{NAD}$, $1.2 \mu \mathrm{M}$ phenazine methosulfate, $0.4 \mathrm{mM}$ MTT and $3 \mathrm{~mL}$ ethanol (Arulsekar and Parfitt, 1986). ADH bands appeared within $20 \mathrm{~min}$ and development was allowed to proceed for an additional $30 \mathrm{~min}$ before the reaction was stopped by rinsing in water.

\section{RESULTS AND DISCUSSION}

Figures 1 and 2 show ADH and LDH activities in shoots and roots of two cultivars of maize seedlings under flooding. On day 0 , the activities of $\mathrm{ADH}$ and $\mathrm{LDH}$ in the shoots of both cultivars were low. Under the stress, ADH activity in the shoots of both cultivars increased rapidly up to day 2 and leveled off, while LDH activity did not change for $3 \mathrm{~d}$ (Fig. 1). Increase in $\mathrm{ADH}$ activity was greater in cv. Jelly Bantam than in cv. Popcorn. The maximum ADH activity was 4.0 and 2.4 times that in the shoots of non-flooding controls for cv. Jelly Bantam and Popcorn, respectively.

Similarly, in the roots of both cultivars, ADH activity increased sharply and LDH activity remained unchanged (Fig. 2). Increase in ADH activity was greater in cv. Jelly Bantam than

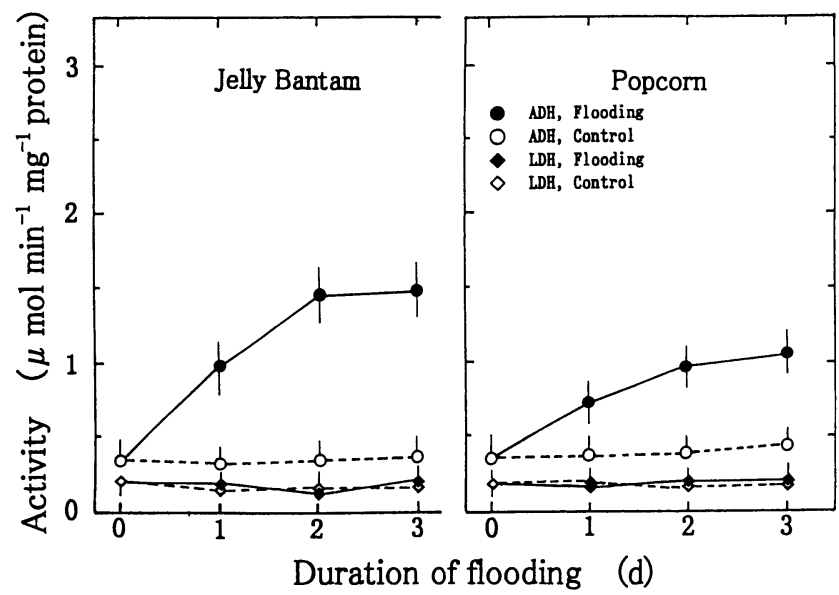

Fig. 1 Changes in the level of ADH and LDH activity in shoots of cv. Jelly Bantam and Popcorn under flooding stress.

Control seedlings were kept in air. Means \pm SE from three experiments with at least three assays for each determination. 


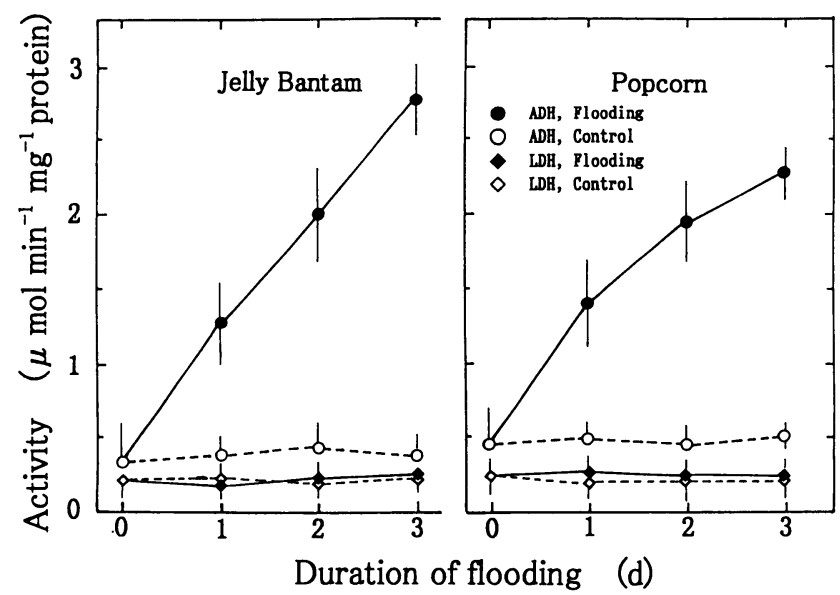

Fig. 2 Changes in the level of ADH and LDH activity in roots of cv. Jelly Bantam and Popcorn under flooding stress.

Control seedlings were kept in air. Means \pm SE from three experiments with at least three assays for each determination.
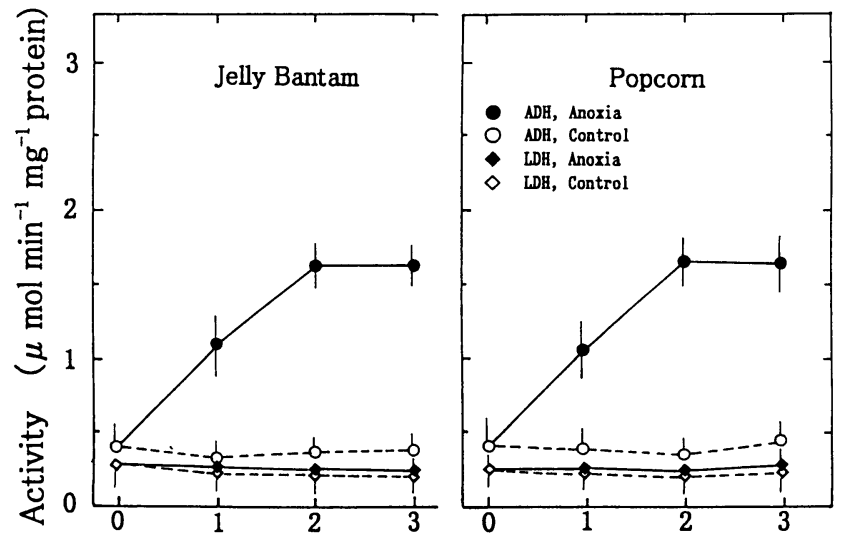

Duration of anoxia (d)

Fig. 3 Changes in the level of ADH and LDH activity in shoots of cv. Jelly Bantam and Popcorn under anoxic stress.

Control seedlings were kept in air. Means \pm SE from three experiments with at least three assays for each determination.

in cv. Popcorn. By day 3, the ADH activity increased 7.3 and 4.5 times that in the roots of non-flooding controls for cv. Jelly Bantam and Popcorn, respectively. These results indicate that the flooding stress increased ADH activity in the roots and the shoots of cv. Jelly Bantam and Popcorn but did not increase LDH activity (Figs. 1 and 2). Induced ADH was 2 times more active in the roots than in the shoots of both cultivars and was more active in cv. Jelly Bantam than in cv. Popcorn.

Figures 3 and 4 show ADH and LDH activities in shoots and roots of cv. Jelly Bantam and Popcorn exposed to anoxia. The maximum ADH activity was 4.3 and 3.5 times that in the shoots of non-anoxic controls for cv. Jelly Bantam and Popcorn, respectively, and 10 and 6 times that in the roots of non-anoxic controls for cv. Jelly Bantam and Popcorn, respectively. 


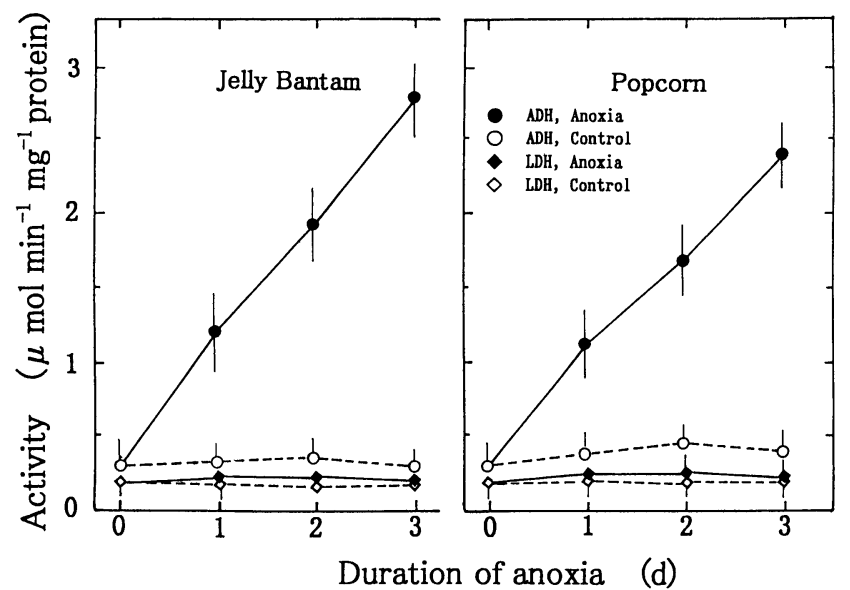

Fig. 4 Changes in the level of ADH and LDH activity in roots of cv. Jelly Bantam and Popcorn under anoxic stress.

Control seedlings were kept in air. Means \pm SE from three experiments with at least three assays for each determination.
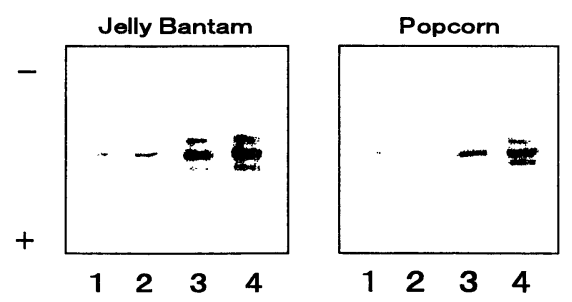

Fig. 5 Isozyme composition of ADH in shoots and roots of cv. Jelly Bantam and Popcorn exposed to anoxic stress for $2 \mathrm{~d}$.

Control seedlings were kept in air. Lane 1: control, shoots; lane 2: control, roots; lane 3: anoxia, shoots; lane 4: anoxia, roots.

The pattern of changes in the activities of ADH and LDH in the seedlings exposed to the anoxic stress was similar to those in the seedlings exposed to the flooding stress (Figs. 1-4). The anoxic stress increased ADH activity but did not change LDH activity for $3 \mathrm{~d}$. Induced $\mathrm{ADH}$ was 1.5 times more active in the roots than in the shoots of both cultivars. Plant ADH enzymes that have been examined are dimers and the two subunits of ADH are encoded by two unlinked genes (Gottlieb, 1982 ; Sachs and Ho, 1986). The products of these genes dimerize randomly to yield three electrophoretically distinct isozymes: ADH1-ADH1 homodimer, ADH1-ADH2 heterodimer, and ADH2-ADH2 homodimer (Gottlieb, 1982; Newman and VanToai, 1991). However, all isozymes could not be found in each plant tissue due to the limited expression of the specific ADH isozymes (Chourey and Widholm, 1980; Xie and Wu, 1989 ; Ke et al., 1994). Using polyacrylamide gel electrophoresis, only one ADH band was identified in extracts of the shoots and the roots of both cultivars under non-anoxic stress and three $\mathrm{ADH}$ isozemes were identified in the extracts under anoxic stress (Fig. 5). These results indicate that the anoxic stress may increase in ADH activity due to activation of ADH subunit translation.

These results suggest that the flooding and the anoxic stresses increase ethanolic fermentation but do not increase lactic fermentation. Since the ADH induction was greater in the 
roots than in the shoots of both cultivars, and greater in cv. Jelly Bantam than in cv. Popcorn, the ethanolic fermentation may be accelerated more in the roots than in the shoots of both cultivars, and more in cv. Jelly Bantam than in cv. Popcorn. This acceleration could allow glycolysis to continue due to consumption of pyruvate and regeneration of NAD (Davies, 1980 ; Kennedy et al., 1992 ; Rivoal and Hanson, 1994). When oxygen becomes limiting, glycolysis has been shown to be accelerated in many plants and the glycolytic pathway was considered to replace the Krebs cycle as the main source of energy (Kennedy et al., 1992). Thus, ethanolic fermentation could be essential for the plant's survival during oxygen limiting conditions (Davies, 1980 ; Ricard et al., 1994 ; Zhang and Greenway, 1994). Maize seedlings showed an increase in $\mathrm{ADH}$ activity under the flooding and the anoxic stresses, which may allow to continue the glycolysis and to produce some ATP, permitting the seedlings to survive under the stresses.

\section{REFERENCES}

Arulsekar, S., Parfitt, D. E. 1986. Isozyme analysis procedures for stone fruits, almond, grape, walnut, pistachio, and fig. HortScience 21 : 928-933.

Bradford, M. M. 1976. A rapid and sensitive method for the quantitation of microgram quantitties of protein utilizing the principle of protein-dye binding. Anal. Biochem. $72: 248-254$.

Chourey, P., Widholm, J. 1980. Tissue specific alcohol dehydrogenase isozyme variation in carrot: whole plant versus in vitro cultured cells. In Vitro $16: 571-574$.

Davies, D. D. 1980. Anaerobic metabolism and the production of organic acids. In "The Biochemistry of Plants Vol. 2" (ed. by Davies, D. D.). Academic Press, New York, p 581-611.

Good, A. G., Muench, D. G. 1993. Long-term anaerobic metabolism in root tissue. Plant Physiol. 101 : $1163-1168$.

Gottlieb, L. P. 1982. Conservation and duplication of isozymes in plants. Science 216: 373-380.

Hoffman, N. E., Bent, A. F., Hanson, A. D. 1986. Induction of lactate dehydrogenase isozymes by oxygen deficit in barley root tissue. Plant Physiol. 82: 658-663.

Kato-Noguchi, H., Watada, A. E. 1997. Effects of low oxygen atmosphere on ethanolic fermentation in fresh-cut carrots. J. Am. Soc. Hortic. Sci. 122 : 107-111.

Ke, D., Yahia, E., Mateos, M., Kader, A. A. 1994. Ethanolic fermentation of 'Bartlett' pears as influenced by ripening stage and atmospheric composition. J. Am. Soc. Hortic. Sci. 119 : 976-982.

Kennedy, R. A., Rumpho, M. E., Fox, T. C. 1992. Anaerobic metabolism in plants. Plant Physiol. $100: 1-6$.

Lin, C. H., Lin, C. H. 1992. Physiological adaptation of waxapple to waterlogging. Plant Cell Environ. 15 : 321-328.

Millar, A. A., Olive, M. R., Dennis, E.S. 1994. The expression and anaerobic induction of alcohol dehydrogenase in cotton. Biochem. Genet. 32 : 279-299.

Newman, K. D., VanToai, T. T. 1991. Cell biology and molecular genetics. Developmental regulation and organ-specific expression of soybean alcohol dehydrogenase. Crop Sci. 31 : 1253-1257.

Perata, P., Alpi, A. 1991. Ethanol-induced injuries to carrot cells: the role of acetaldhyde. Plant Physiol. 95 : 748-752.

Ricard, B., Couée, I., Raymond, P., Saglio, P.H., Saint-Ges, V., Pradet, A. 1994. Plant metabolism under hypoxia and anoxia. Plant Physiol. Biochem. 32 : 1-10.

Rivoal, J., Hanson, A.D. 1994. Metabolic control of anaerobic glycolysis. Plant Physiol. 106 : 1179-1185.

Roberts, J. K. M., Callis, J., Jardetzky, O., Walbot, V., Freeling, M. 1984. Cytoplasmic acidosis as a determinant of flooding intolerance in plants. Proc. Natl. Acad. Sci. U. S. A. 81 : 6029-6033.

Sachs, M. M., Ho, T.-H. D. 1986. Alteration of gene expression during environmental stress in plants. Annu. Rev. Plant Physiol. 37 : 363-376.

Voesenek, L. A. C. J., Banga, M., Rijnders, J. H. G. M., Visser, E.J. W., Harren, F. J. M., Brailsford, R. W., Jackson, M. B., Blom, C. W. P. M. 1997. Laser-driven photoacoustic spectroscopy : what we can do 
with it in flooding research. Ann. Bot. 79: 57-65.

Xie, Y., Wu, R. 1989. Rice alcohol dehydrogenase genes : anaerobic induction, organ specific expression and characterization of cDNA clones. Plant Mol. Biol. 13 : 53-68.

Zhang, Q., Greenway, H. 1994. Anoxia tolerance and anaerobic catabolism of aged beetroot storage tissues. J. Exp. Bot. $45: 567-575$.

\title{
〈和文抄録〉
}

\section{冠水と酸素欠乏ストレスがトゥモロコシ芽生えのアルコール脱水素醭素と 乳酸脱水素酻素に与える影響}

\section{加藤 尚・郡 拓 也・斎藤 英 雄}

\author{
香川大学農学部
}

研究の目的は，冠水と酸素欠乏ストレスがトウモロコシの呼吸代謝に与える影響を明らかにす ることにある.そのため本研究では，トウモロコシの 2 品種 (ジェリーバンタム, ポップコーン) の芽生えに冠水と酸素欠乏ストレスを与え，これらのストレスがアルコール脱水素酵素 (ADH) と乳酸脱水素酵素 (LDH) の活性に与える影響，およびアルコール発酵と乳酸発酵の重要性を調べ た. 冠水と酸素欠乏ストレスは, 両品種の芽生えのシュートと根において ADH 活性を増加させた が, LDH 活性は増加させなかった。この ADH 活性の増加は, いずれのストレスでも, 両品種と もに根でシュートより大きかった. また, 冠水ストレスは, ジェリーバンタムでポップコーンより $\mathrm{ADH}$ 活性を増加させたが, 酸素欠乏ストレスでは, 両品種間で差がなかった，また，電気泳動に よる $\mathrm{ADH}$ アイソザイム分析の結果, これらのストレスによって, 対照区で発現している ADHア イソザイム (1 種類) のバンドが著しく濃くなり, 新たに 2 種類の ADH アイソザイムバンドが両 品種で確認できた.この結果は, これらのストレスは ADH タンパク質の合成量を増加させたこと を示唆している. 以上の結果は, トウモロコシ芽生えにおいて, 冠水と酸素久乏ストレスは, ADH 活性を増加させアルコール発酵を促進させること, LDH 活性は増加させず乳酸発酵を促進しない ことを示唆している.また，この $\mathrm{ADH}$ 活性の増加は, $\mathrm{ADH}$ タンパク質の合成量が増加したため であると考えられる。 